\title{
Co-Expression of $\mathrm{CD}_{133^{+}} / \mathrm{CD} 44^{+}$ in Human Colon Cancer and Liver Metastasis
}

\author{
ANTONIA BELLIZZI,' SINTO SEBASTIAN,' PASQUALE CEGLIA,' MATTEO CENTONZE, ' \\ ROSA DIVELLA, ${ }^{2}$ ELVIRA FOGLIA MANZILLO, ${ }^{3}$ AMALIA AZZARITI, ${ }^{4}$ NICOLA SILVESTRIS, ${ }^{5}$ \\ SEVERINO MONTEMURRO, ${ }^{6}$ COSIMO CALIANDRO, ${ }^{6}$ RAFFAELE DE LUCA, ${ }^{6}$ \\ GIUSEPPE CICERO, ${ }^{7}$ SERGIO RIZZO, ${ }^{7}$ ANTONIO RUSSO, ${ }^{7 *}$ MICHELE QUARANTA, ${ }^{2}$ \\ GIOVANNI SIMONE, ${ }^{3}$ AND ANGELO PARADISO'
}

I'Invasion and Metastatization Laboratory, Department of Experimental Oncology, National Cancer Centre "Giovanni Paolo II", Bari, Italy

${ }^{2}$ Clinical Pathology Laboratory, Department of Experimental National Cancer Centre “Giovanni Paolo II”, Bari, Italy

${ }^{3}$ Department of Pathology, National Cancer Centre “Giovanni Paolo II”, Bari, Italy

${ }^{4}$ Clinical and Preclinical Pharmacology Unit, Department of Experimental National Cancer Centre "Giovanni Paolo II”, Bari, Italy

${ }^{5}$ Medical and Experimental Oncology Unit, National Cancer Centre "Giovanni Paolo II", Bari, Italy

${ }^{6}$ Department of Surgical Oncology, National Cancer Centre “Giovanni Paolo II”, Bari, Italy

${ }^{7}$ Section of Medical Oncology, Department of Surgical and Oncological Sciences, University of Palermo, Palermo, Italy

Although relatively good therapeutic results are achieved in non-advanced cancer, the prognosis of the advanced colon cancer still remains poor, dependent on local or distant recurrence of the disease. One of the factors responsible for recurrence is supposed to be cancer stem cells (CSCs) or tumor-initiating cells, which are a population of cancer cells with ability to perpetuate themselves through self-renewal and to generate differentiated cells, thought to be responsible for tumor recurrence. This study globally approach the possible role of tissue-derived stem cells in the initiation of colon cancer and its metastatic process in the liver. Fresh surgical specimens from colon cancer, non-tumor tissue and liver metastasis were obtained directly from the operating room, examined, and immediately processed. CSCs were selected under serum-free conditions and characterized by CD44 and CDI 33 expression levels. CD I $33^{+} /$CD $44^{+}$cell populations were then investigated in paraffin-embedded tissues and circulating tumor cells isolated from peripheral blood of the same group of colon cancer patients. Our data demonstrate that metastatic properties of cell populations from blood and liver metastasis, differently from primitive tumors, seem to be strictly related to the phenotype CDI33 positive and CD44 positive.

J. Cell. Physiol. 228: 408-4I5, 20I3. (c) 20I2 Wiley Periodicals, Inc.

Colon cancer is the second leading cause of cancer-related death. The majority of these deaths are due to metastasis, with the liver easily the most common site of deposit (LeGolvan and Resnick, 2010).

Combining surgery and chemotherapy in the treatment of patients with colon hepatic metastases is increasingly becoming the standard of care. However, controversy remains regarding the juxtapositioning of chemotherapy and surgery, the duration of chemotherapy, and particularly, the use of preoperative chemotherapy in the treatment of patients with initially resectable metastases (Nordlinger et al., 2010).

Cancer metastasis has been explained by at least two models: a progression model and an initiating model. In the former, metastatic capacity is acquired during cancer progression in a subpopulation of cells through sequential genetic mutations or epigenetic alterations (Gray, 20l0), in genes associated with proteolysis of local extracellular matrix attachments (Nagashima et al., 1997), adhesive alterations (Furger et al., 200I), angiogenesis (Weber, 2008), viable vascular dissemination, distant embolization, and survival in a new environment (Folkman, 1990; Hynes, 2003; Bird et al., 2006). However, not all of these genetic alterations occur during the process of liver metastasis (Gray, 20l0). In the initiation model, cells with metastatic potential are determined by early mutational events in a progenitor cell, named cancer stem cell
(CSCs) or tumor-initiating cells (TIC; Clarke and Fuller, 2006; Polyak and Hahn, 2006; Odoux et al., 2008), even if few data support the hypothesis of its role in the colon metastatic process in humans (Horst et al., 2009b; Puglisi et al., 2009; Ju et al., 20l I).

CD44 and CD 33 have already been validated as informative markers of stem cells in both primary tumors and xenografts (O'Brien et al., 2007; Ricci-Vitiani et al., 2007). CDI33, originally known as $\mathrm{ACI} 33$, is a glycoprotein also known in humans and rodents as Prominin I (PROMI; Kawamoto et al.,

Contract grant sponsor: Italian Ministry of Health, "Programma Integrato Oncologia (PIO) 2007".

*Correspondence to: Antonio Russo, Section of Medical Oncology, Department of Surgical and Oncological Sciences, Università di Palermo, Via del Vespro 127, 90127 Palermo, Italy.

E-mail: antonio.russo@usa.net

Manuscript Received: 19 March 2012

Manuscript Accepted: 18 June 2012

Accepted manuscript online in Wiley Online Library (wileyonlinelibrary.com): 27 June 2012

DOI: 10.1002/jcp.24I45 
2010). It is the founding member of pentaspan transmembrane glycoproteins (5-transmembrane, 5-TM), which was specifically regarded as the colon CSC-surface markers. CDI33 has been used to identify and isolate cancer initiating cells from human colon cancer and it has been demonstrated that $\mathrm{CDI} 33^{+}$cells are able to maintain themselves as well as differentiate and re-establish tumor heterogeneity upon serial transplantation in vivo (O'Brien et al., 2007; Ricci-Vitiani et al., 2007). CD44 is a cell surface glycoprotein involved in cell-cell interactions, cell adhesion, and migration. It was identified as the cell-surface markers of breast cancer and also recently observed to be related to the distant metastasis of colon cancer (Huang et al., 2012).

Currently, there are some studies addressing the CDI33 and CD44 co-expression of CSC antigens in colon cancer patients (Horst et al., 2009a; Salnikov et al., 2009). CD44/CD 133 co-expression was significantly higher in colon cancers with early liver metastases compared to those without early liver metastases and co-expression was also associated with poorest prognosis (Huang et al., 20I2), suggesting that CDI33 and CD44 proteins co-expression in colon cancer may be a potential biomarker for early liver metastases. Indeed, Chen et al. $(20 \mathrm{II})$ demonstrated that FACS sorted CDI $33^{+} / \mathrm{CD} 44^{+}$ HCTI 16 cells are undifferentiated, endowed with extensive self-renewal and epithelial lineage differentiation capacity in vitro, more invasive in vitro and responsible solely for liver metastasis in vivo. However, CDI33 and CD44 expression status and its relation to liver metastasis is still controversial.

A recent study (Hou et al., 20 I I) showed the critical role of $\mathrm{CDI} 33^{+/} \mathrm{CD}_{4} 4^{+}$tumor cells in hematogenous metastasis of liver cancers, underlying that CDI33 is responsible for tumor growth and CD44 is important for invasion; two important factors in tumor metastasis. Their data also suggest that $\mathrm{CDI} 33^{+}$cells act as TIC-like populations, however were not necessarily highly invasive, and that CD44 was a marker of an invasive, but not tumorigenic, sub-population. In addition to CDI33, CD44 has a critical role in tumor metastasis. Moreover, based on studies of $\mathrm{HCC}$ cell lines, $\mathrm{CD} / 33^{+}$and $\mathrm{CD} 44^{+}$were proposed to be markers of TICs in liver cancers (Zhu et al., 2010). Therefore, CDI33 and CD44 could be regarded as markers of metastasis-facilitating pathways through which liver tumor metastasis is jointly promoted.

Therefore, starting from these observations, in this study we have generated stem cell-enriched human colonosphere cultures from fresh samples deriving from the same group of colon cancer and liver metastasis specimens under serum-free culture conditions, comparing the sphere forming potential of the clones isolated from the primary culture coming from both compartments and the differences observed in the corresponding non-tumor counterpart, adjacent to the neoplastic lesion. We have established long-term culture spheres from the three compartments, analyzing the expression of CD44 and CDI33.

Indeed, we have examined colon cancer specimens and circulating tumor cells (CTC) to investigate the CDI33 and CD44 expression and localization.

\section{Materials and Methods Patients}

Biological tissues for laboratory assays were obtained from 2 I patients with a first diagnosis of primary colon cancer with $(n=I I)$ or without $(n=10)$ liver metastasis. All patients were consecutively treated with primary surgery at the Gastrointestinal Surgery Unit of NCC Bari, Italy. Before undergoing routine surgery, all patients signed an informed consent authorizing the Institute to use their removed biological tissues for research purposes. Routine staging procedures were adopted for disease staging according to UICC criteria (Greene and Sobin, 2002). Just after surgical removal of the colon and, if any, of liver metastasis, tissues were macroscopically analyzed by the pathologist who performed a sampling from the primary tumor, from adjacent normal mucosa (located not less than $10 \mathrm{~cm}$ from the primary site), and from liver metastasis. H\&E staining confirmed the diagnosis of colon cancer in all primary and metastatic sites as well the absence of cancer cells in normal mucosa. About $100 \mathrm{mg}$ of tissue without fat and necrosis was placed in sterile tubes with culture medium on ice. Patients with liver metastasis were categorized as the metastatic group (MI); those without liver metastases as the nonmetastatic group (M0).

\section{Isolation and expansion of colon stem cell cultures}

After sampling, biological samples were processed as described previously (Cammareri et al., 2008). The obtained tissue fragments were washed extensively with PBS and were mechanically dissociated using scalpels and vigorous trituration to yield small fragments $\left(<\mathrm{I} \mathrm{mm}^{3}\right)$ and single cells. Enzymatic digestion was performed using collagenase/hyaluronidase (Stemcell

Technologies, Vancouver, Canada) in DMEM/FI 2 containing $5 \mathrm{mM}$ Hepes (Sigma, St. Louis, MO) for $2 \mathrm{~h}$ at $37^{\circ} \mathrm{C}$. The suspension was then filtered through a $100-\mu \mathrm{m}$ pore size to separate the tissue fragments from the single cells. The single cell suspension was cultured in advanced DMEM/FI 2 (Life Technologies, Monza, Italy) supplemented with $0.6 \%$ BSA (Sigma), $0.6 \%$ glucose (Sigma), $2 \mathrm{mM}$ L-glutamine (Euroclone, SPA, Pero, Milano), $9.6 \mu \mathrm{g} / \mathrm{ml}$ putrescin (Sigma), $6.3 \mathrm{ng} / \mathrm{ml}$ progesterone (Sigma), $5.2 \mathrm{ng} / \mathrm{ml}$ sodium selenite (Sigma), $25 \mu \mathrm{g} / \mathrm{ml}$ insulin (Sigma), $100 \mu \mathrm{g} / \mathrm{ml}$ apotransferrin (Sigma), $5 \mathrm{mM}$ Hepes (Sigma), $10 \mathrm{ml}$ antibiotic-antimycotic (Life Technologies, Monza, Italy), and $4 \mu \mathrm{g} / \mathrm{ml}$ Heparin (Sigma). Growth factors $[20 \mathrm{ng} / \mathrm{ml}$ EGF (Peprotech, London, UK) and $10 \mathrm{ng} / \mathrm{ml}$ bFGF (Peprotech)] were added to the cell culture medium freshly each week. All cell culture was carried out in non-tissue culture treated petri at $37^{\circ} \mathrm{C}$ in a $5 \% \mathrm{CO}_{2}$ humidified incubator.

The viable cells were counted using a light microscope by trypan blue dye exclusion test at day 7. Surviving immature tumor cells slowly proliferate, and grow as non-adherent spheres. The formation of such spheres, containing about 50 cells, takes 2 months. Sphere formation was scored as follows: $(-)$ no sphere observed; $(+)$ two spheres per field.

\section{Cytospin cell preparation and immunocytochemical staining of CD44 and CDI33}

Cells were centrifuged at $800 \mathrm{rpm}$ for $5 \mathrm{~min}$, washed with PBS, and re-suspended in PBS. The cells were attached to coated microscope slides (Bio Optica, Milano, Italy) in a Cyto-Tek centrifuge (Sakura Finetek, Alphen Aan Den Rijn, Netherlands) at 2,000 rpm for $10 \mathrm{~min}$ and dried overnight on a slide warmer at $37^{\circ} \mathrm{C}$. They were then fixed with acetone and stained. Primary antibodies specific for CDI33 (Abcam, Cambridge, UK), CD44 (DakoCytomation, Glostrup, Denmark) were used, with primary antibody binding detected using corresponding Dako EnVision System-HRP Labelled Polymer secondary antibodies (DakoCytomation) and AEC Substrate Chromogen (DakoCytomation). The cells were counterstained with Mayer's hematoxylin (DakoCytomation). After incubation, cells were washed with PBS, and incubated with biotinylated link for $30 \mathrm{~min}$, peroxidase-labeled streptavidin for $30 \mathrm{~min}$ and 3-amino-9ethylcarbazole substrate-chromogen (Labelled StreptavidinBiotin2 System-Horseradish Peroxidase; DakoCytomation) for 15 min in the dark. After PBS washing, the slides were counterstained with hematoxylin and mounted with aqueous mounting medium (DakoCytomation). For negative controls, the primary antibody was omitted and replaced by PBS.

Photomicrographs of cytospin preparations were acquired under bright field illumination with a Leica DMLB optical microscope (Leica, Cambridge, UK) and analyzed with Leica IMI000 software. 


\section{Immunohistochemical staining of CD44 and CDI33}

Double immunostaining with antibodies for detection of CD44 and CDI 33 was performed on paraffin-embedded tissue sections and cytospins, using primary antibodies specific for CDI33 (Abcam), CD44 (DakoCytomation), and Alexa 488 goat anti-rabbit and the Alexa 568 goat anti-mouse immunoglobulin GI secondary antibodies conjugate (Invitrogen). Tissue sections were then mounted with aqueous mounting medium (DakoCytomation). For negative controls, the primary antibody was omitted and replaced by PBS. Images were obtained on a BX40 microscope (Olympus, Tokyo, Japan) with a SenSys I40IE Photometrics CCD camera.

\section{Immunohistochemical evaluation}

The scoring was performed twice by two persons in a blinded fashion. CDI33 and CD44 staining was detected mainly in the membrane and was evaluated as the percentage of immunoreactive cells with respect to the total analyzed. The result was the mean of 15-20 random field at $40 \times$ magnification.

\section{Collection of blood samples}

Fifteen milliliters of peripheral blood were collected from each participant in a vacutainer system with lithium-heparin before surgery. A written consent should be obtained from all patients prior to enrolment in the study, and the Ethical Committee of the $\mathrm{NCl}$ approved the protocol which was in accord with the ethical guidelines of the 1975 Declaration of Helsinki Whole. A control group found to be healthy from laboratory data was enrolled among donors $(\mathrm{N}=30)$. Their median age was 50 years (range: 40-70 years).

\section{Magnetic labeling}

Fifty milliliters of anti-coagulated blood were centrifuged with $400 \mathrm{~g}$ for $35 \mathrm{~min}$. Buffy coat were collected into $50-\mathrm{ml}$ conical tubes. For magnetic labeling, the cells were first permeabilized using CellPerm Solution ( $40 \mathrm{ml}$ ) from the Carcinoma Cell Enrichment Kit (Miltenyi Biotec, Bergisch Gladbach, Germany) and incubated for 5 min at room temperature. Fixation was done using $5 \mathrm{ml}$ of Cell Fix Solution for $30 \mathrm{~min}$ at room temperature. The cells were then washed twice in dilution buffer. Two hundred microliters of FcR Blocking Reagent (Miltenyi Biotec) was used for the prevention of unspecific binding. Two hundred microliters of anti-cytokeratin
(7/8) Micro Bead was used for magnetic labeling. The magnetic labeling was performed at room temperature for $45 \mathrm{~min}$. Finally, the cells were washed once in cell stain solution and resuspended in $\mathrm{I} \mathrm{ml}$ of dilution buffer for magnetic cell separation.

\section{Magnetic separation of cytokeratin 7/8-positive tumor cells}

For magnetic separation, the labeled cells were passed through MS+ (Miltenyi Biotec) separation columns that had been equilibrated with dilution buffer. The negative cells were washed off the column with $3 \mathrm{ml}$ of dilution buffer. The retained cells were eluted from the column outside the magnetic field by pipetting I ml of dilution buffer onto the column and the cellular suspension was filtered through a mesh with $30-\mu \mathrm{m}$ diameter holes.

\section{Immuncytochemical labeling and microscopic analysis}

Cells were magnetically separated as described above, and the enriched cell fraction was spun down on slides using a cytocentrifuge. Slides were air-dried overnight at room temperature. Fast Red TR/Naphthol AS-MX Substrate Solution was added to cell spots for $15 \mathrm{~min}$ in humidity chamber at $25^{\circ} \mathrm{C}$. Slides were then stained with dilute Meyer's hemalum solution I:2 in $100 \mathrm{mM}$ of Tris- $\mathrm{HCl}, \mathrm{pH} 8.2$, washed twice for I min in double distilled water, and coverslipped using glycerin plus PBS (I:I).

\section{Results}

Tumor tissues of 21 patients with primary colon cancer, together with matched adjacent normal tissues, were collected; I I patients had also liver metastasis. Clinical pathological characteristics and biological specimens of each patient are summarized in Table I. Fresh tissues (Fig. IA) were processed and after dissection, viable cells were obtained from 17 out of I 8 tumor tissues, I I out of I 8 normal mucosa, and I I out of I I liver metastasis (Table 2). We evaluated the growth potential of these primary cells under serum-free conditions. First generation of colon spheres (Fig. IB) were successfully cultured in II out of 17 samples from tumors, in 9 out of $1 \mathrm{I}$ from metastasis and in 6 out of II from adjacent normal tissues (Table 2). To assess whether the ability to form spheres was maintained during the time of culture, cells were expanded and after 5 months (Table 2) 5 out of 17 samples from tumor tissues, 6 out of II from liver metastasis, and 2 out of II from non-

TABLE I. Summary of patient population, tumor sample information, and phenotype characteristics

\begin{tabular}{|c|c|c|c|c|c|c|c|c|c|c|c|c|c|c|c|c|c|c|}
\hline \multirow[b]{2}{*}{ Sample } & \multirow[b]{2}{*}{ Age/sex } & \multirow{2}{*}{$\begin{array}{l}\text { Tumor } \\
\text { stage }\end{array}$} & \multirow[b]{2}{*}{ Grade } & \multicolumn{5}{|c|}{ Tumor } & \multicolumn{5}{|c|}{ Liver metastasis } & \multicolumn{5}{|c|}{ Normal tumor adjacent tissue } \\
\hline & & & & Vitality & Spheres & CSCs & CDI33 & CD44 & Vitality & Spheres & CSCs & CDI33 & CD44 & Vitality & Sphere & $\mathrm{SCs}$ & CDI33 & CD44 \\
\hline I & $66 / M$ & T2NOMO & 2 & + & + & - & - & + & & & & & & + & + & - & - & - \\
\hline 2 & $70 / M$ & T2NOMO & 2 & + & - & - & - & + & & & & & & + & + & - & - & - \\
\hline$\overline{3}$ & $64 / M$ & T3NOMO & 2 & + & - & - & - & + & & & & & & - & & & & \\
\hline 4 & $81 / F$ & T3N2M0 & 3 & + & - & - & - & + & & & & & & + & + & + & - & + \\
\hline 5 & $68 / M$ & T3NOMO & 3 & + & - & - & - & - & & & & & & + & - & - & - & - \\
\hline 6 & $68 / M$ & $\mathrm{~T} 4 \mathrm{~N} 2 \mathrm{M} 0$ & 3 & + & - & - & - & - & & & & & & + & - & - & - & - \\
\hline 7 & $62 / M$ & T2NOMO & 2 & + & + & - & - & - & & & & & & + & + & - & - & + \\
\hline 8 & $42 / M$ & T3NIMO & 3 & + & + & - & + & + & & & & & & + & - & - & - & + \\
\hline 9 & $82 / M$ & $\mathrm{~T} 4 \mathrm{~N} 2 \mathrm{MO}$ & 3 & + & + & + & + & - & & & & & & - & & & & \\
\hline 10 & $70 / M$ & T3NIMO & 3 & + & + & + & + & - & & & & & & + & - & - & - & + \\
\hline II & $63 / F$ & T4NIMI & 3 & + & + & + & + & + & + & + & + & + & + & + & + & + & - & + \\
\hline 12 & $52 / M$ & T3N2MI & 2 & + & + & + & + & + & + & + & + & + & + & - & & & & \\
\hline 13 & $87 / F$ & $\mathrm{~T} 4 \mathrm{~N} 2 \mathrm{MI}$ & 2 & + & + & + & + & + & + & + & + & + & + & - & & & & \\
\hline 14 & $73 / M$ & T3N2MI & 3 & - & + & + & + & + & + & - & & & & & & & & \\
\hline 15 & $67 / M$ & $\mathrm{~T} 4 \mathrm{~N} 2 \mathrm{MI}$ & 2 & + & + & - & + & + & + & + & + & + & + & + & + & - & - & + \\
\hline 16 & $72 / M$ & T3N2MI & 3 & + & + & - & + & + & + & + & - & + & + & - & & & & \\
\hline 17 & $61 / F$ & T3N2MI & 2 & + & + & - & + & + & + & - & - & + & + & - & & & & \\
\hline 18 & $63 / F$ & T4NOMI & 3 & + & - & - & + & + & + & + & - & + & + & + & - & - & - & - \\
\hline 19 & $66 / F$ & T4N2MI & 3 & & & & & & + & + & - & - & - & & & & & \\
\hline 20 & $64 / F$ & T3NIMI & 2 & & & & & & + & - & - & + & + & & & & & \\
\hline 21 & $74 / M$ & T3NIMI & 3 & & & & & & + & + & + & + & + & & & & & \\
\hline
\end{tabular}

$F$, female; $M$, male. 


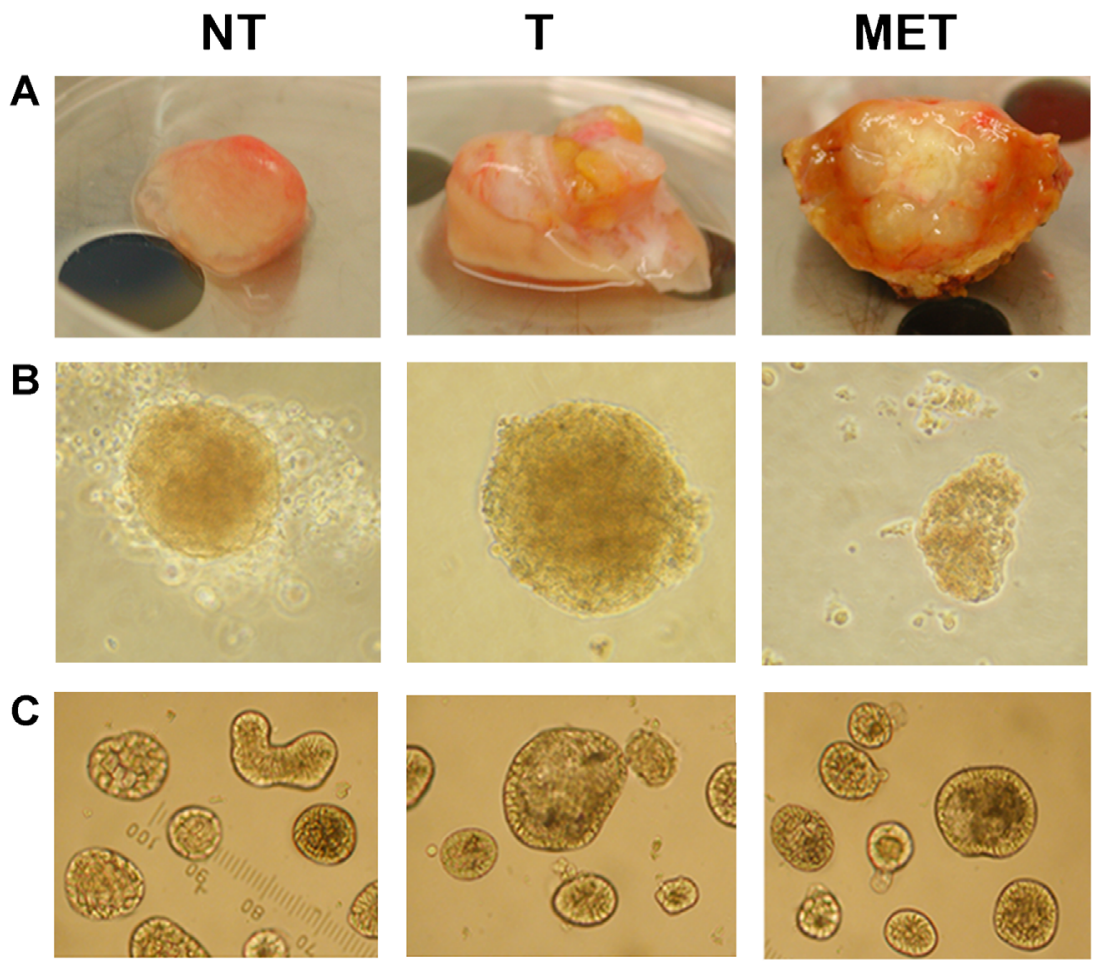

Fig. I. A: Fresh tissues of primary colon cancer (T), matched adjacent normal tissues (NT), and liver metastasis (MET). B: Phase contrast photo of first and $(C)$ third generation colon spheres growth under serum-free conditions $(40 \times)$.

tumor tissues were able to form spheroids of second and third generation (Fig. IC).

The presence of $\mathrm{CD}_{4} 4^{+}$cells and $\mathrm{CDI} 33^{+}$cells was evaluated at two isolation steps (Table 2): on the cell suspensions obtained I week after sample processing, representative of naïve samples (Fig. 2A), and in clones obtained after 5 months of cell selection (Fig. 3). CD44 was detectable in 13 out of 17 samples from primary tumors, in 6 out of II from normal adjacent mucosa, and in 10 out of II from metastasis. All non-tumor specimens were CDI33-, whereas II out of
17 tumor and 10 out of II metastasis samples were $\mathrm{CDI} 33^{+}$. $\mathrm{CDI} 33^{+}$cells were significantly higher in the tumor compartment than in the metastatic compartment, and higher in liver metastasis than in non-tumor tissue $(21.6 \pm 1.8 \mathrm{vs}$. $5.4 \pm 1.09$ vs. $0.56 \pm 0.3)$. The $\mathrm{CD}_{4}{ }^{+}$cells were significantly higher in the liver metastasis than tumor and non-tumor compartment (I $2.6 \pm \mathrm{I} .19$ vs. $10.7 \pm \mathrm{I} .37$ vs. $9.18 \pm 2.2)$. Then, we confirmed CD44 and CD 133 expression levels in the clones obtained after 5 months of cells selection (Fig. 3 ) and we found that $100 \%$ of the CSCs isolated from the non-tumor

TABLE 2. Summary of patients phenotype and functional characteristics

\begin{tabular}{|c|c|c|c|}
\hline & NT & $\mathrm{T}$ & Liver metastasis \\
\hline Number & 18 & 18 & 11 \\
\hline \multicolumn{4}{|l|}{ Naive sample } \\
\hline Vitality & $11 / 18$ (6I\%) & $17 / 18$ (94.4\%) & II/II (100\%) \\
\hline \multicolumn{4}{|l|}{ Expression markers/patients } \\
\hline CDI33 & $0 / 11(0 \%)$ & $1 \mathrm{l} / 17$ (64.7\%) & $10 / 11$ (90.9\%) \\
\hline CD44 & $6 / I I(54.5 \%)$ & $13 / 17(76.5 \%)$ & $10 / 11(90.9 \%)$ \\
\hline \multicolumn{4}{|l|}{ Markers expression mean } \\
\hline$\%$ CDI33 positive cells & $0.56 \pm 0.3$ & $21.6 \pm 1.8$ & $5.4 \pm 1.09$ \\
\hline \%CD44 positive cells & $9.18 \pm 2.2$ & $10.7 \pm 1.37$ & $12.6 \pm 1.19$ \\
\hline Sphere production (20 days) & $6 / 11$ (54.5\%) & $1 \mathrm{I} / 17(64.7 \%)$ & $9 / 11(81.8 \%)$ \\
\hline SCs isolated after 5 months cultured & $2 / 11(18.2 \%)$ & $5 / 17(29.4 \%)$ & $6 / 11(54.5 \%)$ \\
\hline \multicolumn{4}{|l|}{ SCs phenotype } \\
\hline $\mathrm{CDI} 33^{+} / \mathrm{CD} 44^{+}$ & 0 & $3 / 5(60 \%)$ & $6 / 6(100 \%)$ \\
\hline $\mathrm{CDI} 33^{+} / \mathrm{CD} 44^{-}$ & 0 & $2 / 5(40 \%)$ & 0 \\
\hline $\mathrm{CDI} 33^{-} / \mathrm{CD} 44^{+}$ & $2 / 2(100 \%)$ & 0 & 0 \\
\hline $\mathrm{CD} 133^{-} / \mathrm{CD}_{4} 4^{-}$ & 0 & 0 & 0 \\
\hline \multicolumn{4}{|l|}{ P-e sample } \\
\hline $\mathrm{CDI}^{3} 3^{+} / \mathrm{CD} 44^{+}$cells/patients & $0 / 18(0 \%)$ & $9 / 18(50 \%)$ & $10 / 11(90.9)$ \\
\hline$\% \mathrm{CDI} 33^{+} / \mathrm{CD} 44^{+}$cells & $1.3 \pm 0.2$ & $13.8 \pm 1.1$ & $8.5 \pm 0.7$ \\
\hline
\end{tabular}

P-e, paraffin-embedded; SCs, stem cells. 
A

CD133

NT

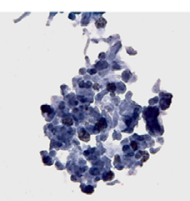

CD44

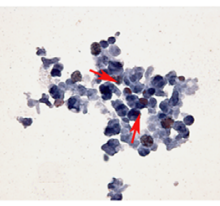

T
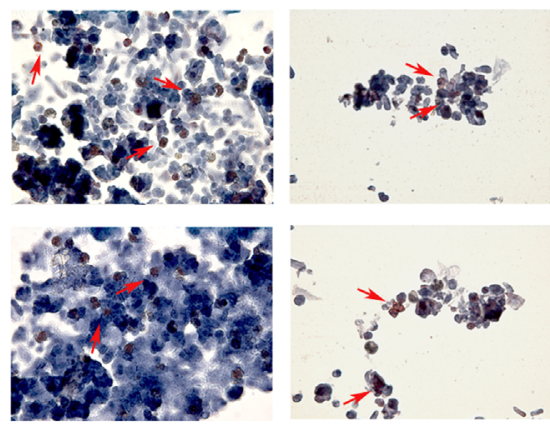

MET

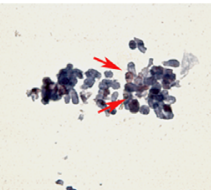

B

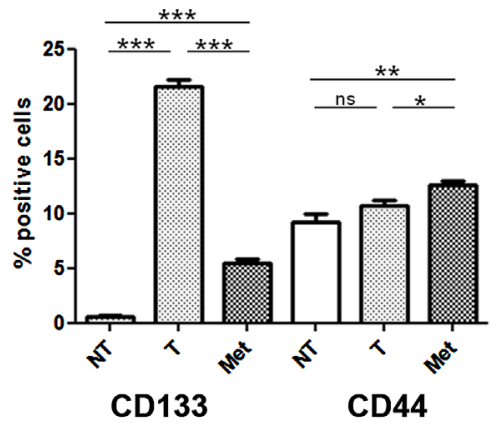

Fig. 2. CD44 and CDI 33 expression levels in tumor cells clusters (20×). CD44 and CDI33 expression were evaluated. A,B: One week after samples processing in tumor cells clusters.

compartments were $\mathrm{CDI} 33^{-} / \mathrm{CD}_{4} 4^{+}$; $\mathrm{CSC}$ isolated from the tumor compartment were $\mathrm{CDI} 33^{+} / \mathrm{CD} 44^{+}$in $60 \%$ of cases and $\mathrm{CDI} 33^{+} / \mathrm{CD}_{44^{-}}$in $40 \%$; CSCs from metastasis were all CD44 ${ }^{+} / \mathrm{CD} 133^{+}$.

We also performed immunofluorescence analysis to determine the proportion of $\mathrm{CDI} 33^{+} / \mathrm{CD} 44^{+}$putative tumorigenic cells within each tumor, scanning for the presence of the FITC and TRITC staining in the same cell (Fig. 4). Immunohistochemical staining for CDI33 (red, first column) and CD44 (green, second column) showed membrane localization of the two proteins in epithelial tumor cells localized at the base of the crypt (Fig. 4B-D), or in tumor cells scattered throughout the tumor sections (Fig. 4A). Small number of $\mathrm{CDI} 33^{+} / \mathrm{CD} 44^{+}$cells were observed only in primary tumors of patients who develop liver metastasis (Fig. 4D). Metastasis consists of cancer cells showing membrane CDI33/CD44 accumulation (Fig. 4E).

We evaluated the difference in the presence of $\mathrm{CD} 44^{+} /$ $\mathrm{CDI} 33^{+}$cells and found that are significantly higher in the tumor compartment than in the metastatic once and higher in liver metastasis than in non-tumor tissue $(13.8 \pm \mathrm{I}$.I vs. $8.5 \pm 0.7$ vs. $1.3 \pm 0.2$ ).

\section{Dapi}

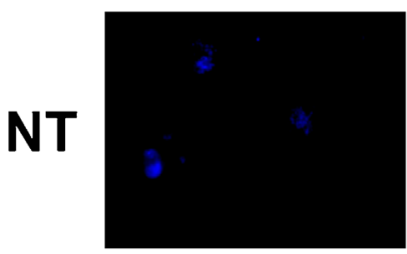

CD133
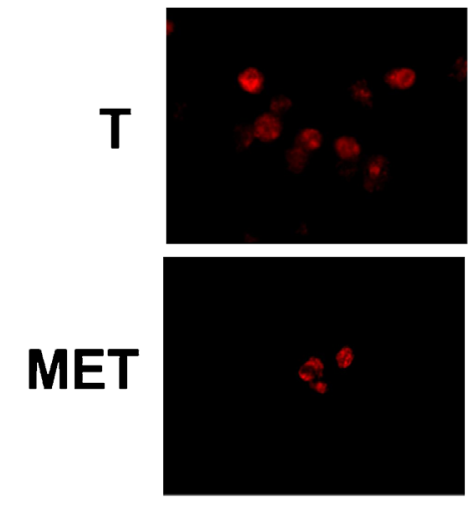

CD44

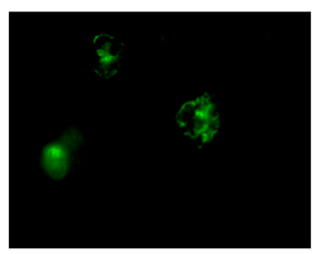

CD44
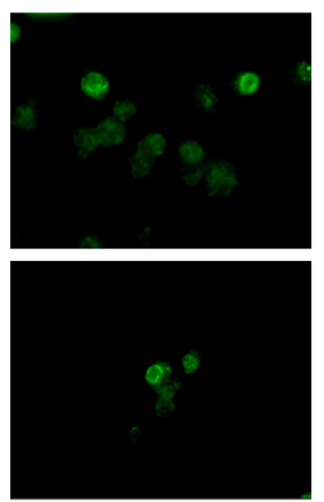

Merge

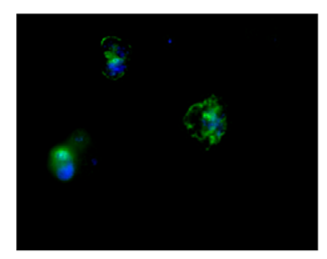

Merge
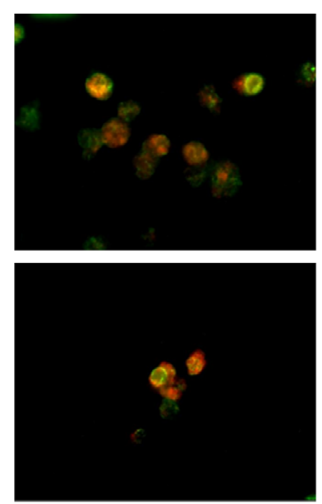

Fig. 3. Representative CD44 and CDI33 staining in colon spheres growth for 5 months under serum-free conditions. 

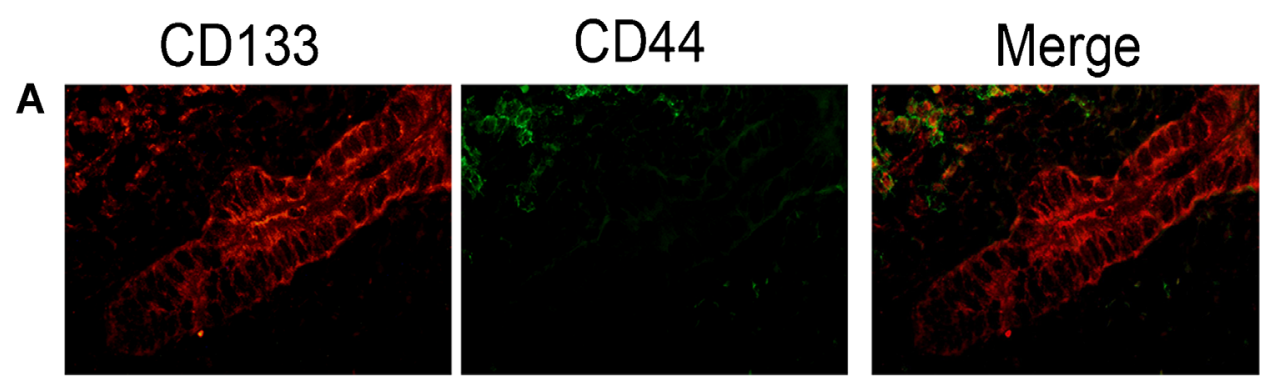

B
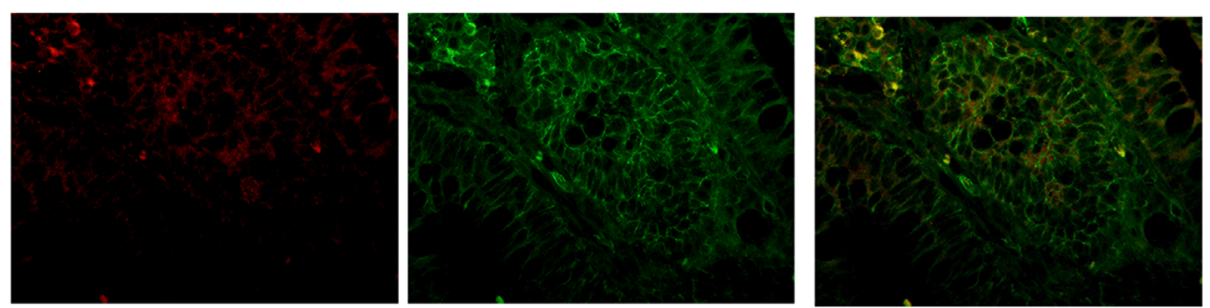

C
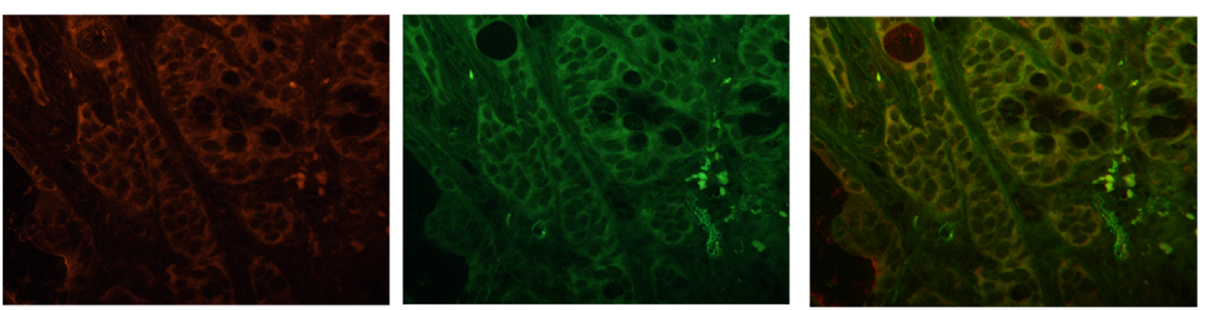

D
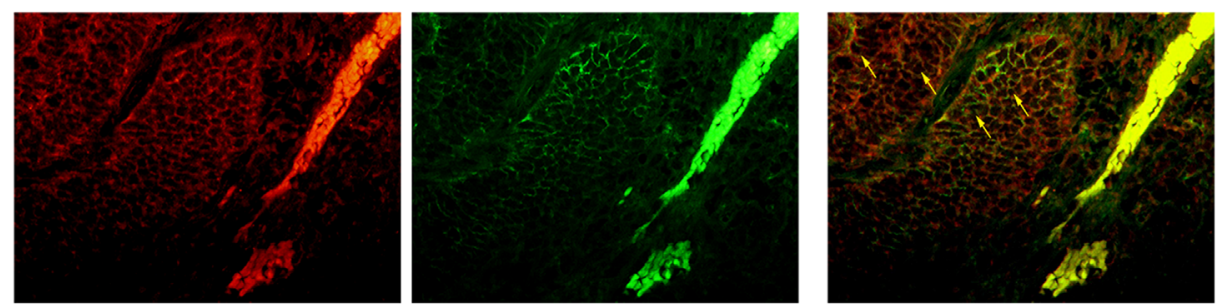

$\mathbf{E}$
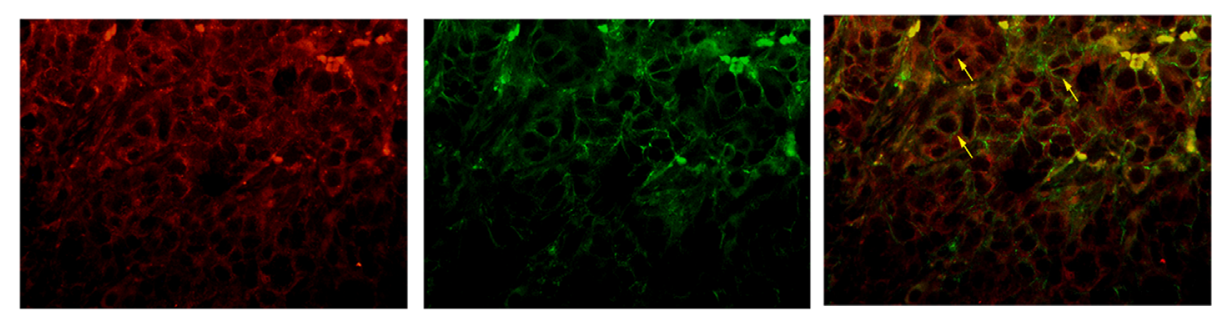

Fig. 4. Representative immunohistochemical staining for $\mathrm{CD} / 33$ (red, first column) and CD44 (green, second column) in adjacent serial sections of human colon cancer formalin-fixed, paraffin-embedded specimens of primary (A-D) and metastatic (E) colon cancers. The primary tumors were

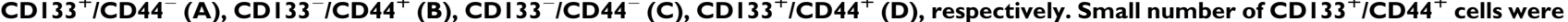
scattered throughout the tumor sections (arrow in D,E). C: CDI $33^{-} / C D 44^{-}$tumor in which only a specific signals are visualized.

When investigating the difference between the tumor phenotype in the non-metastatic group (10 patients) and the metastatic group (eight patients), the colocalization analysis showed more $\mathrm{CDI} 33^{+} / \mathrm{CD} 44^{+}$cells in the metastatic group (I00\%) compared to the non-metastatic group (I0\%). CDI33-/ CD44 ${ }^{+}$cells were detected in $40 \%$ of the tumors, while a complete lack of both proteins was evident in $30 \%$ of tumors. The percentage of $\mathrm{CDI} 33^{+} / \mathrm{CD} 44^{+}$cells in the primary tumor and the corresponding liver metastasis in the metastasis group is presented in Table 3 . We did not find a significant difference in the number of $\mathrm{CDI} 33^{+} / \mathrm{CD} 44^{+}$cells between the primary tumors and the corresponding liver metastasis $(60.8 \pm 27.99$ vs.
$50.3 \pm 16.38$; Mann Whitney $P$ value $>0.05)$, suggesting that they have similar cells of origin.

Peripheral blood from the eight metastatic colorectal cancer patients was collected and processed as described in methods and CTCs were isolated. We found in 6 out of 8 detectable population of CTCs ranging from 20 to 250 per $15 \mathrm{ml}$ of blood (Fig. 5A). CTC retain three different types of cells or cell clumps, as follows: cytokeratin-positive single-standing tumor cells (Fig. 5B); cytokeratin-positive cell clumps containing at least two cells, consisting only of cytokeratin-positive cells (Fig. 5C); mixed cell clusters containing more than three cells, with at least one of them cytokeratin-positive (Fig. 5D). In this 
TABLE 3. Percentage of $\mathrm{CDI} 33^{+} / \mathrm{CD} 44^{+}$cells in the primary tumor and the corresponding liver metastasis in patients with metastases

\begin{tabular}{lcc}
\hline Sample & Tumor & Liver metastasis \\
\hline 11 & 8.3 & 36.1 \\
12 & 64.5 & 35 \\
16 & 100 & 70 \\
14 & 84 & 50 \\
15 & 23.5 & 43.3 \\
16 & 60.8 & 58.3 \\
17 & 72.2 & 73.3 \\
18 & 28.1 & 47.2 \\
19 & 73.5 & 69.2 \\
20 & 45.6 & 85.4 \\
21 & 40 & 50.3 \\
Median & 60.8 & 50.30 \\
SD DEV & 27.99 & 16.38 \\
\hline
\end{tabular}

study, no cytokeratin-positive cells were found in the blood of healthy donors. We found $20 \%$ of cancer cells showing membrane CDI33/CD44 accumulation; positive cells were not usually simple, rather they were doublets or clusters. The

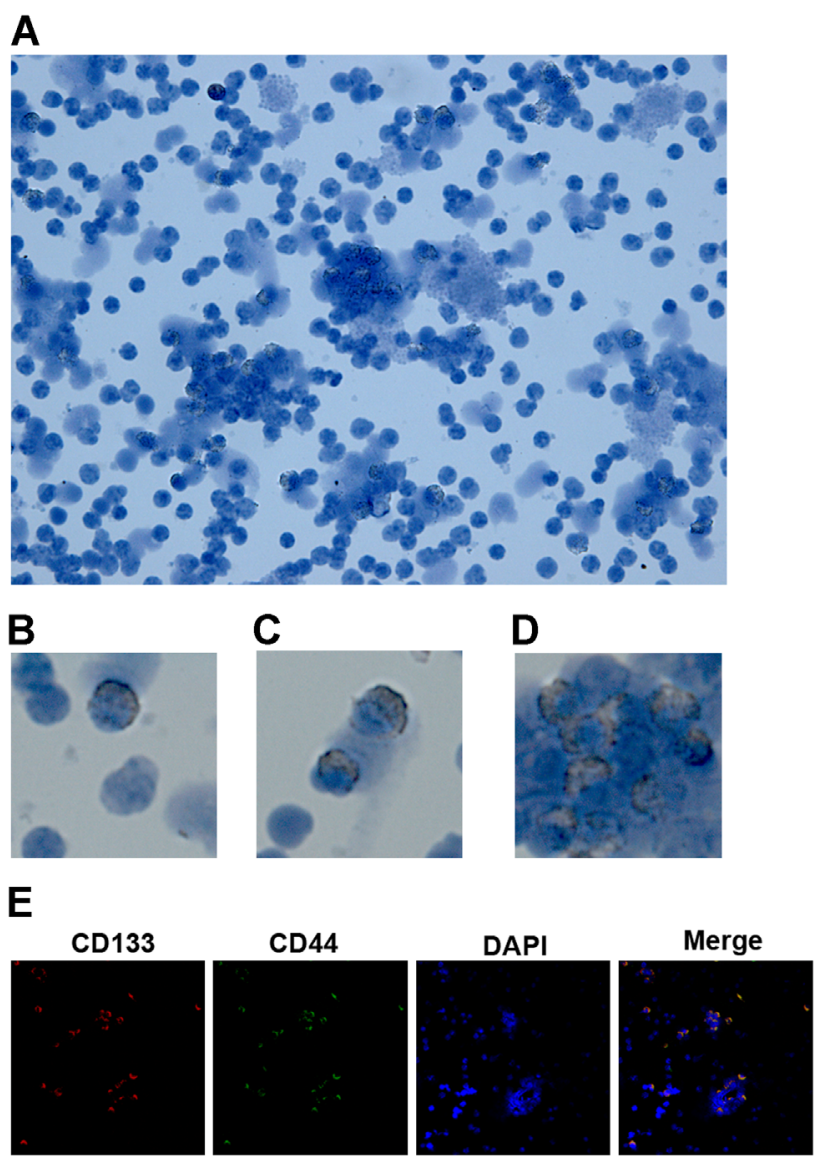

Fig. 5. A) Representative CTCs found in peripheral blood from metastatic colorectal cancer patients. Cells retain three different types of cells or cell clumps: B) cytokeratin-positive single-standing tumor cells; C) cytokeratin-positive cell clumps containing at least two cells, consisting only of cytokeratin-positive cells; D) mixed cell clusters containing more than three cells, with at least one of them cytokeratin-positive. E) Representative CTCs processed for immunofluorescence microscopy as described in the Materials and Methods. Cells were immunostained with an anti-CD44 mouse monoclonal antibody (green) and an anti-CDI 33 rabbit polyclonal antibody (red).
$\mathrm{CDII} 3^{+} / \mathrm{CD}_{4} 4^{+}$cells were attached to $\mathrm{CDI} 33^{-} / \mathrm{CD}_{4} 4^{-}$cells; they appeared either in doublets or in mixed clusters.

\section{Discussion}

Cancer stem cell theory has profound implications in terms of cancer therapy. Indeed, current treatments are hardly able to completely eradicate cancer cells and are often complicated by the occurrence of tumor recurrence and/or metastasis. One hypothesis is that current chemotherapy attacks the bulk of cancer without affecting stem cells which can re-grow after treatment, and, eventually, develop the changes responsible for the occurrence of drug-resistance (Guzman et al., 2002; Guan et al., 2003; Dean et al., 2005).

Even though the precise contribution of $\mathrm{CDI} 33^{+} / \mathrm{CD}_{4} 4^{+}$ TICs in mediating colon cancer metastasis in human is contradictory (Shmelkov et al., 2008), recently, it was demonstrated that $\mathrm{CDI} 33^{+} / \mathrm{CD} 44^{+}$cells are undifferentiated, endowed with extensive self-renewal and epithelial lineage differentiation capacity in vitro, more invasive in vitro and responsible solely for liver metastasis in vivo (Chen et al., 20 I I). In addition, recent evidence suggests that CDI33 and CD44 proteins co-expression in colon cancer may be indicative for early liver metastases (Huang et al., 20I I).

To try to shed light on this problem, cells isolated from fresh tissue specimens were cultured under non-adherent conditions to form colon spheres. We found that long-term, non-adherent culture conditions generate spheres of slowly proliferating cells; single cells, dissociated from spheres, express both CD44 and CDI33. Our data emphasize that the marker CDI33 is higher expressed in primary tumor cells than non-tumor cells or metastatic cells. We demonstrated the presence of cells also positive for CD44, in primary colon cancer tissue. $76.5 \%$ of tumor samples and $90.9 \%$ of liver metastases expressed CD44, while only $54.5 \%$ of non-tumor samples did. Indeed $64.7 \%$ of tumors and $90.9 \%$ of metastasis showed CDI33 expression detectable whereas samples from normal tissues were all $\mathrm{CD} / 33^{-}$, in agreement with literature data in which it has been stressed that CDI33 expression was extremely infrequent in normal colon tissues compared to tumor tissues (Fang et al., 20I0), and suggesting that the increased number of CDI 33 cells in cancer samples maybe a result of their oncogenic transformation. However, we found that the percentage of CDI33 positive cells was significantly higher in the tumor compartment than in metastatic compartment ( $21.6 \pm 1.8$ vs. $5.4 \pm 1.09$ ) suggesting that CDI33 expression only could be responsible for tumor growth. While the higher rate of CD44 cells in liver metastasis suggests its involvement in tumor metastasis.

These observations are enforced by those obtained dividing the non-metastatic patients from the metastatic ones and observing their tumor phenotype (Table 4): in the metastatic group all sample $\mathrm{CDI} 33^{+} / \mathrm{CD} 44^{+}$, while in the non-metastatic group there was a prevalence of the $\mathrm{CDI} 33^{+} / \mathrm{CD}_{4} 4^{-}$ phenotype.

CTC are believed to be directly involved in the biology of the metastatic process and recent observations support the hypothesis that expression of CDI 33 in the peripheral blood of

TABLE 4. Summary of primary tumor phenotype in the non-metastatic and metastatic group

\begin{tabular}{lcc}
\hline & $M 0$ & $M I$ \\
\hline $\mathrm{CDI33}^{+} / \mathrm{CD} 44^{+}$ & $10 \%(1 / 10)$ & $100 \%(8 / 8)$ \\
$\mathrm{CDI}^{-}$ & $30 \%(3 / 10)$ & 0 \\
$\mathrm{CDI}^{-} / 3^{+} / \mathrm{CD} 44^{-}$ & $20 \%(2 / 10)$ & 0 \\
$\mathrm{CDI}^{-}$ & $40 \%(4 / 10)$ & 0 \\
\hline
\end{tabular}

MO, non-metastatic group; MI, metastatic group. 
patients affected with CRC might identify high-risk patients by detecting putative circulating CSCs that might be responsible for disease progression after apparently radical surgery (Pilati et al., 20I2). We found detectable population of CTCs in $75 \%$ of metastatic colon cancer patients: $20 \%$ of CTCs showed membrane CDI33-/CD44 ${ }^{+}$accumulation; positive cells were not usually simple, rather they were doublets or clusters. The $\mathrm{CDII} 3^{+} / \mathrm{CD} 44^{+}$cells were attached to $\mathrm{CD} / 33^{-} / \mathrm{CD} 44^{-}$cells; they appeared either in doublets or in mixed clusters. Our analysis supports the premises that CTCs represent a sampling of the phenotypic cell types present in the primary and metastatic tumor deposits, and the possibility that CTCs consist of a combination of cells with malignant potential, stem cell characteristics and actively migrating cells that may go on to form liver metastatic foci.

Collectively, these results suggest that $\mathrm{CDI} 33^{+}$colon cancer cells might play an important role in both primary tumors as well as in metastatic lesions but metastasis of the liver seems to be strictly related to the phenotype CDI $33^{+}$and $C D 44^{+}$. Our data underline the importance of $\mathrm{CDI} 33^{+} / \mathrm{CD} 44^{+} \mathrm{CSCs}$ in liver metastasis thus warranting further studies on the role(s) of this subset of cells in the liver metastatic process.

\section{Acknowledgments}

This study was partially supported by the Italian Ministry of Health, "Programma Integrato Oncologia (PIO) 2007."

\section{Literature Cited}

Bird NC, Mangnall D, Majeed AW. 2006. Biology of colorectal liver metastases: A review. J Surg Oncol 94:68-80.

Cammareri P, Lombardo Y, Francipane MG, Bonventre S, Todaro M, Stassi G. 2008. Isolation and culture of colon cancer stem cells. Methods Cell Biol 86:3III-324.

Chen KL, Pan F, Jiang H, et al. 20I I. Highly enriched CDI33(+)CD44(+) stem-like cells with CDI33(+)CD44(high) metastatic subset in HCTII6 colon cancer cells. Clin Exp Metastasis 28:75!-763.

Clarke MF, Fuller M. 2006. Stem cells and cancer: Two faces of eve. Cell I24: I I I I- I I I5.

Dean M, Fojo T, Bates S. 2005. Tumour stem cells and drug resistance. Nat Rev Cancer 5:275-284.

Fang DD, Kim YJ, Lee CN, et al. 2010. Expansion of CD I33(+) colon cancer cultures retaining stem cell properties to enable cancer stem cell target discovery. Br J Cancer I02: 1265-1275. Folkman J. 1990. What is the evidence that tumors are angiogenesis dependent? J Natl Cancer Inst 82:4-6.
Furger KA, Menon RK, Tuck AB, Bramwell VH, Chambers AF. 200I. The functional and clinical roles of osteopontin in cancer and metastasis. Curr Mol Med I:62I-632.

Gray J. 2010. Cancer: Genomics of metastasis. Nature 464:989-990.

Greene FL, Sobin LH. 2002. The TNM system: Our language for cancer care. J Surg Oncol $80: 119-120$.

Guan Y, Gerhard B, Hogge DE. 2003. Detection, isolation, and stimulation of quiescent primitive leukemic progenitor cells from patients with acute myeloid leukemia (AML). Blood 101:3142-3149.

Guzman ML, Swiderski CF, Howard DS, et al. 2002. Preferential induction of apoptosis for primary human leukemic stem cells. Proc Natl Acad Sci USA 99:16220-16225.

Horst D, Kriegl L, Engel J, Kirchner T, Jung A. 2009a. Prognostic significance of the cancer stem cell markers CD 133, CD44, and CDI66 in colorectal cancer. Cancer Invest 27.844 850 .

Horst D, Scheel SK, Liebmann S, Neumann J, Maatz S, Kirchner T, Jung A. 2009b. The cancer stem cell marker $\mathrm{CDI} 33$ has high prognostic impact but unknown functional relevance for the metastasis of human colon cancer. J Pathol 219:427-434.

Hou Y, Zou Q, Ge R, Shen F, Wang Y. 20I I. The critical role of CDI33(+)CD44(+/high) tumor cells in hematogenous metastasis of liver cancers. Cell Res 22:259-272.

Huang X, Sheng Y, Guan M. 2012. Co-expression of stem cell genes CDI33 and CD44 in colorectal cancers with early liver metastasis. Surg Oncol 21:103-107.

Hynes RO. 2003. Metastatic potential: Genetic predisposition of the primary tumor or rare, metastatic variants-or both? Cell II3:82I-823.

Ju HX, An B, Okamoto Y, Shinjo K, et al. 20II. Distinct profiles of epigenetic evolution between colorectal cancers with and without metastasis. Am J Pathol 178:1835-1846.

Kawamoto H, Yuasa T, Kubota Y, et al. 2010. Characteristics of CDI33(+) human colon cancer SW620 cells. Cell Transplant 19:857-864

LeGolvan MP, Resnick M. 2010. Pathobiology of colon cancer hepatic metastases with an emphasis on prognostic factors. J Surg Oncol 102:898-908.

Nagashima Y, Hasegawa S, Koshikawa N, et al. 1997. Expression of matrilysin in vascular endothelial cells adjacent to matrilysin-producing tumors. Int J Cancer 72:44I-445.

Nordlinger B, Vauthey JN, Poston G, Benoist S, Rougier P, Van Cutsem E. 20I0. The timing of chemotherapy and surgery for the treatment of colon liver metastases. Clin Colorectal Cancer 9:212-218.

O'Brien CA, Pollett A, Gallinger S, Dick JE. 2007. A human colon cancer cell capable of initiating tumour growth in immunodeficient mice. Nature 445:106-110.

Odoux C, Fohrer H, Hoppo T, et al. 2008. A stochastic model for cancer stem cell origin in metastatic colon cancer. Cancer Res 68:6932-6941.

Pilati P, Mocellin S, Bertazza L, Galdi F, Briarava M, Mammano E, Tessari E, Zavagno G, Nitti D. 2012. Prognostic value of putative circulating cancer stem cells in patients undergoing hepatic resection for colorectal liver metastasis Ann Surg Oncol 19:402-408.

Polyak K. Hahn WC. 2006. Roots and stems: Stem cells in cancer. Nat Med 12:296-300.

Puglisi MA, Sgambato A, Saulnier N, et al. 2009. Isolation and characterization of CDI33+ cell population within human primary and metastatic colon cancer. Eur Rev Med Pharmacol Sci 13:55-62.

Ricci-Vitiani L, Lombardi DG, Pilozzi E, et al. 2007. Identification and expansion of human colon-cancer-initiating cells. Nature 445: III-115.

Salnikov AV, Kusumawidjaja G, Rausch V, et al. 2009. Cancer stem cell marker expression in hepatocellular carcinoma and liver metastases is not sufficient as single prognostic parameter. Cancer Lett 275:185-193.

Shmelkov SV, Butler JM, Hooper AT, et al. 2008. CDI 33 expression is not restricted to stem cells, and both CDI33+ and CDI33- metastatic colon cancer cells initiate tumors. J Clin Invest II $8: 2111-2120$.

Weber GF. 2008. Molecular mechanisms of metastasis. Cancer Lett 270:181-190.

Zhu Z, Hao X, Yan M, Yao M, Ge C, Gu J, Li J. 2010. Cancer stem/progenitor cells are highly enriched in CDI33+ CD44+ population in hepatocellular carcinoma. Int J Cancer 126:2067-2078. 